\title{
Maximising dairy production by using nitrogen fertiliser and calving early
}

\author{
N.A. THOMSON', A.H.C. ROBERTS', T.G. JUDD ${ }^{3}$ and J.S. CLOUGH ${ }^{3}$ \\ ${ }^{1}$ Ruakura Agricultural Research Station \\ 'Flock House Agricultural Centre \\ 'Taranaki Agricultural Research Station
}

\begin{abstract}
The effects of applying nitrogen $(\mathrm{N})$ fertiliser at $100 \mathrm{kgN} / \mathrm{ha}$ as a split application $(40 \mathrm{kgN} / \mathrm{ha}$ in July/ early August and $60 \mathrm{kgN} / \mathrm{ha}$ in October) and of earlier calving (16 July vs 2 August) on milk solids production and farm profitability were evaluated at the Waimate West Demonstration Farm in South Taranaki. Two systems were comparedover 3 years: calving on 2 August with no $N(\mathrm{LC})$ and calving on 16 July with $\mathrm{N}$ (ECN). In the second and third year calving on 16 July with no $\mathrm{N}$ (EC) was also evaluated. All herds were stocked at 4.0 cows/ ha. Early calving without N (EC) increased the average lactation length/cow by only 2 days because poorer cow condition andless winter supplements required earlier drying off. Milkfat increased by only $13 \mathrm{~kg} / \mathrm{ha}$ and protein by $1 \mathrm{~kg} / \mathrm{ha}$.

Early calving with $\mathrm{N}$ (ECN) increased the average lactation length/cow by 16 days, milkfat by $57 \mathrm{~kg} / \mathrm{ha}$ and protein by $27 \mathrm{~kg} / \mathrm{ha}$. Nitrogen applied in October was more effective ( $\mathrm{kg}$ milk solids $/ \mathrm{kg} \mathrm{N}$ ) at increasing milk solids production (1.08 $\mathrm{kg}$ milk solids $/ \mathrm{kg} \mathrm{N}$ ) than $\mathrm{N}$ applied in late winter $(0.56 \mathrm{~kg}$ milk solids $/ \mathrm{kg} \mathrm{N})$. At 4.0 cows $/$ ha and calving on 16 July, the break-even milkfat price for $\mathrm{N}$ use was $\$ 3.00 / \mathrm{kg}$ fat.
\end{abstract}

Keywords milk solids, production, nitrogen fertiliser, calving date.

\section{Introduction}

In South Taranaki the major limitation to increasing dairy production is low summer rainfall (Roberts \& Thomson 1984). Minimising the effects of summer dry spells through the introduction of more drought tolerant species (Thomson \& Lagan 198 1, Thomson et al 1988) or through feeding supplements over summer (Bryant 1983) have not increased production or have proved to be uneconomic. The adverse effects of a summer dry spell could be minimised by calving earlier. Judd et al (1990) showed in South Taranaki that severe feed restrictions would result from earlier calving unless stocking rate was reduced, or pasture growth in late winter/ early spring increased.

Information provided by O'Connor \& Cumberland (1973), Thomson \& Roberts (1982) and Roberts \& Thomson (1989) on pasture responses in Taranaki to applications of nitrogen $(\mathrm{N})$ fertiliser. shows that dairying systems may be profitable with the strategic use of $\mathrm{N}$. This would be achieved by overcoming the feed shortage in late winter and increasing the amount of conserved feed for summer, through late winter and mid-spring applications of N fertiliser. Holmes (1982) and Bryant et al (1982) conduded that the use of $\mathrm{N}$ in NZ dairying is uneconomic. However, Bryantet al (1982) did show that the use of $\mathrm{N}$ in winter and early spring was profitable if calvingearlicrat ahighstockingratewhenfeedshortages are severe in early lactation.

In future, dairy companies may develop payment systems to provide incentives for increased production outside the spring flush (Paul 1985). With a payment incentive the strategic use of $\mathrm{N}$, earlier calving and more summer supplements may therefore profitably increase dairy production. To evaluate this hypothesis a demonstration programme was run on the Waimate West Demonstration Farm in South Taranaki over 3 years (1987-1990).

\section{Methods}

The soil type is Egmont brown loam (Campbell \&Wilde 1970). the altitude $90 \mathrm{~m}$ above sea level and the mean annual rainfallis $1070 \mathrm{~mm}$. Pasturesarepredominantely old (greater than 30 years) consisting mainly of perennial ryegrass (Lolium perenne), white clover (Trifolium repens) and a small proportion of other grass species including prairie grass (Bromus catharticus), codksfoot (Dactylis glomerata) and Poa annua. Soil fertility is above average by MAF soil test; ie. $\mathrm{pH}$ 5.8-6.0, Olsen $\mathbf{P}$ greater than 30 and quick test $\mathrm{K}$ greater than 8 .

The first year was established solely as a demonstration of two dairying systems: one calving on 2 August at 4.1 cows/ ha with no N (LC), the other calving on 20 July with $\mathrm{N}$ (ECN) applied in early July and again 
in October to maximise the conservation of surplus pasture in late spring/early summer. The trial layout over the 3 years, 1987-1990 is presented in Table 1 .

For the ECN farmlet, $\mathrm{N}$ was applied as urea over two periods, a policy which was adopted for years 1.2 and 3 .

Table 1 Trial layout.

\begin{tabular}{lcccc}
\hline & $\begin{array}{c}\text { No. } \\
\text { Cows }\end{array}$ & $\begin{array}{c}\text { Area } \\
\text { (ha) }\end{array}$ & $\begin{array}{c}\text { Stocking rate Calving } \\
\text { (cows/ha) }\end{array}$ & date \\
\hline 1987-88 Season Treatment & & & & \\
Late calving (LC) & 70 & 17 & 4.1 & 2 Aug \\
Early calving, N (ECN) & 70 & 17 & 4.1 & 16 July \\
\hline 1988/90 Season Treatment & & & & \\
Late calving (CC) & 46 & 12.0 & 4.0 & 2 Aug \\
Early calving (EC) & 43 & 10.8 & 4.0 & 16 July \\
Early calving, $N$ (ECN) & 43 & 10.8 & 4.0 & 16 July \\
\hline
\end{tabular}

\section{Period 1}

To maximise the response to $\mathrm{N}$, urea application began early in July at $40 \mathrm{kgN} / \mathrm{ha}$. Nitrogen was applied to all paddocks to meet feedrequirements and optimisepasture response to $\mathrm{N}$ for that time of year (Roberts \& Thomson 1989). Nitrogen was applied when the herbage mass of paddocks exceeded $1800 \mathrm{~kg} \mathrm{DM} / \mathrm{ha}(45 \mathrm{~mm})$, orproviding grazing would not occur within 3 weeks, according to the following schedule:

Application date, 2nd week July -\% ECN farmlet treated, 35; 1st week August, 15; 2nd week August, 15; 3rd week August, 20; 4th week August, 15.

\section{Period 2}

From the first week of October, $60 \mathrm{~kg} \mathrm{~N} / \mathrm{ha}$ was applied to all paddocks immediately after grazing (residual herbage mass approximately $2000 \mathrm{~kg} \mathrm{DM} / \mathrm{ha}$ ) to maximise spring growth and increase supplementary feed conserved.

\section{Farmlet Management}

All farmlets were managed similarly using objective criteria for feed demand, residual herbage mass, rotation length and trigger levels for the removal of surplus pasture as either silage or hay (Thomson 1985). Cows were dried off in autumn according to predetermined feed budgets. Feed availability and feed demand were calculated from the current date through to 20 September and drying off dates established to equate the availability of feed with demand and ensure cows calved at a condition score of about 4.5. Budgets were updated fortnightly and particular herds dried off when apparent feed deficits occurred.
The extra pasture conserved (ECN-EC) on the ECN farmlet was fed out to lactating cows in the $\mathrm{ECN}$ herd over summer during periods of pasture shortage. Feed conserved on the LC and EC and that remaining on the ECN farmlet was fed to dry cows over winter.

Rotationlengthsweresimilartonotmalfarmpractice. During winter all paddocks were grazed once (So-100 day rotation), a 30-40 day rotation was maintained from calving to late September/early October, then rotation length was shortened to 20-25 days. In late summer/ autumn therotation was lengthened to 30-40 days before drying off.

\section{Farm Costs/Returns}

Over the three years the total cost of purchasing and applying $\mathrm{N}$ averaged $\$ 1.01 / \mathrm{kg} \mathrm{N}$ applied. Conservation cost were monitored and the costs of the additional feed conserved on the ECN farmlet was calculated at $\$ 0.084 /$ $\mathrm{kg}$ DM. Revenue was based on the final payout of the Kiwi Cooperative Dairy Company for the $1990 / 91$ season at: $\$ 2.30 / \mathrm{kg}$ milkfat, $\$ 3.838 / \mathrm{kg}$ protein and minus $\$ 0.032 /$ litre milk.

\section{Measurements}

\section{Year 1}

Fortnightly herd test for milk yield, fat $\%$ andprotein $\%$ from calving to December, then at monthly intervals from December to drying off. Using a pasture probe, herbage mass was estimated weekly. Average farm cover (kg DM/ha) was calculated using equations of L'Huillier \&Thomson (1988).

Year 2 and 3

Herd testing of all cows for milk yield, fat $\%$ and protein $\%$ 2-weekly from calving to drying off. Throughout lactation herbage mass was estimated in all paddocks weekly using the pasture probe and fortnightly over the winter dry period. From this information herbage mass before and after grazing and average farm cover was calculated and the conservation programme and drying off dates established.

To determine the effect of the two times of $\mathrm{N}$ application on milk solids production over the (19881990) seasons, each season was divided into 3 periods: calving to 12 October, 12 October to 10 January and 10 January to drying off. Production over each period was averaged for the two years.

During September/October (before any paddock was shut for silage) and in March/April, pastures in all paddocks were sampled immediately before grazing for botanical composition (green grass, clover, weeds and 
dead material) and results expressed as percentage of total dry weight.

\section{Results}

Milk solids production

The advantage of $96 \mathrm{~kg} / \mathrm{ha}$ milkfat and $50 \mathrm{~kg} / \mathrm{ha}$ protein (Table 2) in the $1987 / 88$ season to the ECN treatments was not repeated. Over the next two seasons the advantage to ECN was $48 \mathrm{~kg} / \mathrm{ha}$ milkfat, $4 \mathrm{~kg} / \mathrm{ha}$ protein and $73 \mathrm{~kg} /$ ha milkfat, $33 \mathrm{~kg} /$ ha protein in the $1988 / 89$ and $1989 / 90$ seasons respectively. Over the two years of the early vs late calving comparison, the average advantage to early calving was $13 \mathrm{~kg} / \mathrm{ha}$ milkfat and $1 \mathrm{~kg} / \mathrm{ha}$ protein. Nitrogen (ECN vs EC) increased milk solids by an average $48 \mathrm{~kg} / \mathrm{ha}$ milkfat and $17 \mathrm{~kg} / \mathrm{ha}$ protein (Table 3 ).

Table 2 Milk solids production over three years

\begin{tabular}{lccc}
\hline & LC & E C & EC N \\
\hline $1987 / 88$ & & & \\
$\mathrm{~kg} \mathrm{fat/ha}$ & 556 & - & 652 \\
$\mathrm{~kg} \mathrm{protein/ha}$ & 410 & & 460 \\
$1988 / 89$ & & & \\
$\mathrm{~kg} \mathrm{fat} / \mathrm{ha}$ & 564 & 572 & 612 \\
$\mathrm{~kg} \mathrm{protein/ha}$ & 416 & 407 & 420 \\
Lactation days & 211 & 206 & 228 \\
1989/90 & & & \\
$\mathrm{kg} \mathrm{fat/ha}$ & 684 & 700 & 757 \\
$\mathrm{~kg} \mathrm{protein/ha}$ & 509 & 521 & 542 \\
Lactation days & 242 & 252 & 267 \\
\hline Average (3 Seasons) & & & \\
$\mathrm{kg} \mathrm{fat/ha}$ & & & \\
$\mathrm{kg} \mathrm{protein/ha}$ & 603 & - & 672 \\
Average (2 Seasons) & 445 & - & 475 \\
$\mathrm{~kg} \mathrm{fat/ha}$ & & & \\
$\mathrm{kg} \mathrm{protein/ha}$ & 623 & 636 & 684 \\
Lactation days & 463 & 464 & 481 \\
\hline
\end{tabular}

From calving to 12 October, early calving (16 days earlier) increased milk solids production by $27 \mathrm{~kg}$ milkfat/ ha and $10 \mathrm{~kg}$ protein/ha (Table 4). Nitrogen further increased production by $14 \mathrm{~kg} / \mathrm{ha}$ for milkfat and $12 \mathrm{~kg} /$ ha for protein. Over the period of conservation and when the $60 \mathrm{kgN} / \mathrm{ha}$ was applied to the ECN treatment, all treatments produced similarmilkfatbut the ECN treatment produced $13 \mathrm{~kg} / \mathrm{ha}$ less protein, losing all advantage gained from $\mathrm{N}$ application in the first period. The EC treatment was dried off the earliest and in terms of lactation days, lost all benefit of calving early. The cows in the ECN treatment were milked for an additional 19 days, resulting in an extra $36 \mathrm{~kg} / \mathrm{ha}$ of milkfat and $18 \mathrm{~kg} /$ ha of protein, compared with production on the EC treatment.
Table 3 Responsiveness of the dairy system to the strategic use of $\mathbf{N}$ fertiliser for additional late winter pasture and conserved pasture for summer feed (Average kg milk solids/ha 1988/89, 1989/90 seasons)

\begin{tabular}{lccc}
\hline & LC & E C & E C N \\
\hline Calving : 12 October & & & \\
$\mathrm{kg} \mathrm{fat/ha}$ & 185 & 212 & 226 \\
$\mathrm{~kg} \mathrm{protein/ha}$ & 146 & 156 & 168 \\
Lactation days & 55 & 71 & 71 \\
\hline 12 October - IO January & & & \\
$\mathrm{kg} \mathrm{fat} / \mathrm{ha}$ & 270 & 268 & 266 \\
$\mathrm{~kg}$ protein/ha & 198 & 198 & 185 \\
Lactation days & 91 & 91 & 91 \\
\hline 10 January - Dry & & & \\
$\mathrm{kg} \mathrm{fat} / \mathrm{ha}$ & 168 & 156 & 192 \\
$\mathrm{~kg} \mathrm{protein/ha}$ & 119 & 110 & 128 \\
Lactation days & 71 & 67 & 86 \\
\hline Total & & & \\
$\mathrm{kg}$ fat/ha & 623 & 636 & 684 \\
$\mathrm{~kg}$ protein/ha & 463 & 464 & 481 \\
Lactation days & 217 & 229 & 248 \\
\hline
\end{tabular}

Table 4 Advantage of early calving and the application of $\mathbf{N}$ feniliser (average two years).

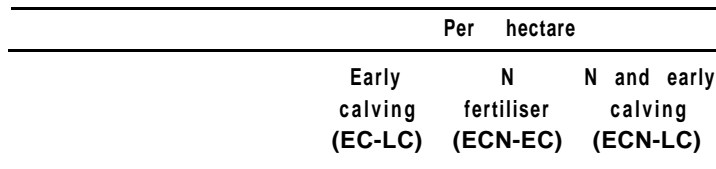

Calving $\cdot 12$ October

$\begin{array}{lccc}\mathrm{kg} \text { fat } & 27 & 14 & 41 \\ \mathrm{~kg} \text { protein } & 10 & 12 & 22 \\ \text { Lactation days } & 16 & 0 & 16\end{array}$

\begin{tabular}{lccc}
\hline 12 October - 10 January & & & \\
kg fat & -2 & -2 & -4 \\
kg protein & 0 & -13 & -13 \\
$\quad$ Lactation days & 0 & 0 & 0 \\
\hline $10 \quad$ Jan-Dry & & & \\
$\quad$ kg fat & -12 & 36 & 24 \\
kg protein & -9 & Ia & 9 \\
$\quad$ Lactation days & -14 & 19 & 5 \\
\hline
\end{tabular}

Total gain

\begin{tabular}{llll}
$\mathrm{kg}$ fat & 13 & 48 & 61 \\
$\mathrm{~kg}$ protein & 1 & 17 & 18 \\
Lactation days & 2 & 19 & 21 \\
\hline
\end{tabular}

Table 5 Pasture conserved for each treatment (bale hay equivalents/ ha) over three seasons (1987-1990)

\begin{tabular}{lllr}
\hline & L C & EC & ECN \\
\hline $1987 / 88$ & 68 & & 96 \\
$1988 / 89$ & 28 & 36 & 44 \\
$1989 / 90$ & 44 & 44 & 80 \\
Average (3 years) & 47 & & 73 \\
Average (2 years) & 36 & 40 & 62 \\
\hline
\end{tabular}


Tabl e 6 Herbage mass (kg DM/ha) levels before and after grazing for milking cows in spring (calving-l December) 1988 and 1989.

\begin{tabular}{|c|c|c|c|c|c|c|}
\hline & \multicolumn{2}{|c|}{ LC } & \multicolumn{2}{|c|}{ EC } & \multicolumn{2}{|c|}{ ECN } \\
\hline & $\mathrm{kgDM} / \mathrm{ha}$ & $S E$ & $\mathrm{kgDM} / \mathrm{ha}$ & SE & kgDM/ha & SE \\
\hline \multicolumn{7}{|l|}{1988} \\
\hline Before grazing & 3240 & 570 & 3040 & 580 & 3270 & 730 \\
\hline After grazing & 1700 & 370 & 1700 & 340 & 1640 & 340 \\
\hline \multicolumn{7}{|l|}{1989} \\
\hline Before grazing & 2900 & 380 & 2720 & 450 & 2800 & 320 \\
\hline After grazing & 1620 & 170 & 1620 & 160 & 1910 & 200 \\
\hline
\end{tabular}

\section{Effects on Pasture}

Over the three years the amount of feed conserved (Table 5) differed between treatments and between years. Conservation was similar (36-40 bales/ha) on the LC and EC treatments and in each year more feed was conserved on the ECN treatment. There was a small difference between years in the absolute levels of herbage mass before and after grazing during the period of conservation (Table 6) but the differences between treatments within years were small andnon-significant.

Tabl e 7 Pasture composition recorded in all paddocks before grazing in spring and summer.

\begin{tabular}{lcccccc}
\hline & \multicolumn{3}{c}{ Spring 1966} & \multicolumn{3}{c}{ Spring 1969} \\
& Grass & Clover & Dead & Grass & Clover & Dead \\
\hline LC & $\mathbf{6 9}$ & 16 & 11 & $\mathbf{5 0}$ & $\mathbf{1 5}$ & $\mathbf{2 5}$ \\
E C & $\mathbf{7 2}$ & $\mathbf{1 2}$ & $\mathbf{1 2}$ & $\mathbf{5 5}$ & $\mathbf{2 2}$ & $\mathbf{2 1}$ \\
ECN & $\mathbf{7 6}$ & 11 & 10 & $\mathbf{5 6}$ & $\mathbf{1 5}$ & $\mathbf{2 5}$ \\
\hline & \multicolumn{3}{c}{ Sumer } & 1988 & \multicolumn{4}{c}{ Summer } & 1989 \\
& Grass & Clover & Dead & Grass & Clover & Dead \\
\hline LC & 58 & $\mathbf{1 3}$ & $\mathbf{2 0}$ & $\mathbf{4 6}$ & $\mathbf{1 6}$ & $\mathbf{3 2}$ \\
E C & 61 & 15 & 18 & $\mathbf{4 4}$ & $\mathbf{1 0}$ & $\mathbf{3 0}$ \\
ECN & $\mathbf{5 8}$ & $\mathbf{1 2}$ & $\mathbf{2 4}$ & $\mathbf{4 5}$ & $\mathbf{1 5}$ & $\mathbf{3 5}$ \\
\hline
\end{tabular}

In no period were any of the pasture components significantly different $(P<0.05)$.

Composition of pasture over spring and summer 1988-1990 (Table 7) did not differ between treatments. In spring 1988 the clover content in the LC treatment was $6 \%$ and $7 \%$ greater than the EC and ECN treatments respectively $(\mathrm{P}<0.08)$.

\section{Economic Analysis}

For the 1988 to 1990 period the overall benefit to early calving was $\$ 32 / \mathrm{ha}$ and the additional benefit to $\mathrm{N}$ fertiliser \$19/ha (Table 8).

\section{Discussion}

From the last two years' data (Table 8) it can be concluded that applying $\mathrm{N}$ had little benefit on farm profitability despite using $\mathrm{N}$ strategically to maximise both the pasture DM response and the utilisation of pastureformilksolidsproduction. A similarconclusion was drawn by Holmes (1982) and Bryant et al (1982). However, if the results of the first year of the demonstration are included (ECN group produced 96 $\mathrm{kg}$ milkfat/ha and $50 \mathrm{~kg}$ protein/ ha more than the LC group) then a different conclusion may be drawn.

From the more intensive programme in the last two years (Table 4), the proportion of the overall response to the ECN system due to calving earlier, and the proportion due to $N$, can be estimated. For the 61 $\mathrm{kg}$ milkfat/ha response to ECN compared with LC, $21 \%$ of the response was due to earlier calving and $79 \%$ due to the N. Similarly for protein, $6 \%$ of the increase to ECN was due to earlier calving and $94 \%$ due to N. Applying this information to the first year it is possible to recalculate the benefits (Table 9) resulting from the three years of application of $100 \mathrm{~kg} \mathrm{~N} / \mathrm{ha}$.

Table 8 Economic assessment of the value (\$/ha of early calving and the application of $\mathrm{N}$ feniliser (average 1988/89 and 1989/90 seasons)

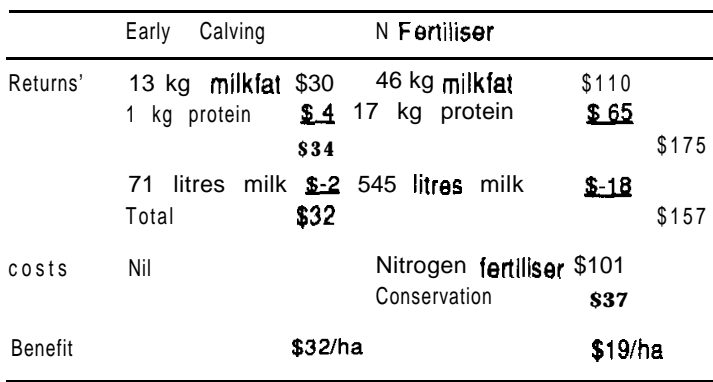

Retums based on the 1990191 final payout of Kimi Cooperative Dain

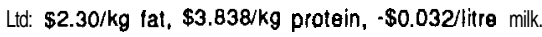


The re-calculation (Table 9) suggests that the preliminary conclusions (Table 8 ) could underestimate the benefits due to $\mathrm{N}$.

When initially designing the programme it was felt that the greatest effect of $\mathrm{N}$ on milk solids would have resulted from the initial application in July/early August. This however was not the case. The initial application of $40 \mathrm{~kg} \mathrm{~N} /$ ha increased total milk solids (fat + protein) by $26 \mathrm{~kg} / \mathrm{ha}$ (Table 4), ie. aresponse of $0.56 \mathrm{~kg}$ milk solids/ $\mathrm{kg} \mathrm{N}$. The increased production from the later application of $\mathrm{N}$ ( $60 \mathrm{~kg} \mathrm{~N} / \mathrm{ha}$ ) increased milk solids by of $65 \mathrm{~kg} / \mathrm{ha}$, i.e. a response of $1.08 \mathrm{~kg}$ milk solids $/ \mathrm{kg} \mathrm{N}$. The response in milk solids production to the later application was achieved through the conservation of additional supplementary feed resulting from the October application of $\mathrm{N}$ and the feeding out of the additional supplement to the ECN herd over summer.

An additional 32 bales of hay/ha were conserved and fed out over summer on the ECN farmlet compared with the EC farmlet. Assuming a bale of hay averages $20 \mathrm{~kg}$ $\mathrm{DM}$, the apparent conversion of the additional DM as supplement to milk fat production (440 kg DM fed as supplement: $36 \mathrm{~kg}$ milkfat) was very high at $12.2 \mathrm{~kg}$ DM/kg milkfat. From a number of short-term studies, Bryant (1983) calculated a conversion of $66 \mathrm{~kg} \mathrm{DM} / \mathrm{kg}$ milkfat. This marked difference in feed conversion efficiency may in part be explained by short term studies not taking into account the effects of supplementary feeding on cow condition and pasture substitution (resulting in higher average farm cover) or by the feed budget approach, allowing herdmanagement torespond to differences in cow condition and farm cover resulting in changes in drying off dates and lactation days. All of these factors were accounted for in the farmlet approach.

Table 9 Re-calculation of the overall benefits to using $\mathbf{N}$ fertiliser (utilising Year 1 data).

Increase in production in Year 1 due to ECN:

$$
\begin{aligned}
& 96 \mathrm{~kg} \text { milkfat/ha } \\
& 50 \mathrm{~kg} \text { protein/ha. }
\end{aligned}
$$

Increase due to $\mathrm{N}$ calculated from ratios established in Years 2 and 3 .

Milkfat $79 \%$ due to $\mathrm{N}=75 \mathrm{~kg} / \mathrm{ha}$, Year 1 Protein $94 \%$ due to $\mathrm{N}=47 \mathrm{~kg} / \mathrm{ha}$, Year 1

The average response to $\mathrm{N}$ over three years:

Milkfat $57 \mathrm{~kg} / \mathrm{ha}$
Protein $27 \mathrm{~kg} / \mathrm{ha}$.

Using the data presented for costs and returns presented In Table 8 the overall benefit to using $\mathrm{N}$ :

$\$ 74 / \mathrm{ha}$ at a $\$ 4.50 / \mathrm{kg}$ fat equivalent payout.
From Table 9 it can be calculated that with 4.0 cows/ ha calving on the 16 July in South Taranaki, the breakeven milkfat payment to applying $100 \mathrm{~kg} \mathrm{~N} / \mathrm{ha}$ was $\$ 3.00 / \mathrm{kg}$ milkfat.

\section{Conclusion}

Nitrogen fertiliser can be profitable for dairying in summer dry environments if the management system maximises the effects on pasture growth and fully utilises the additional DM for milk solids production. Calving should be early and $\mathrm{N}$ should be applied in July to overcome pasture shortage in early lactation. Nitrogen should be applied again in October to maximise growth for conservation for later feeding out over summer.

\section{REFERENCES}

Bryant, A.M.; MacDonald, K.A.; Clayton, D.G. 1982. Effects of nitrogen fertiliser on production of milk solids from grazed pasture. Proceedingsof the New Zealand Grassland Association 43:58-63.

Bryant, A.M. 1983. Dairycattlemanagement: Summer supplementary feeding. Aglink FPP163.

Campbell, LB.; Wilde, R.H. 1970. Soils. Waitmate West County pp24-40. In Land Inventory Survey, Waimate West County. Department of Lands and Survey, Wellington 60p.

Holmes, C.W. 1982. The effect of fertiliser nitrogen on the production of pasture and milk in dairy farmlets: 197 1-74. Proceedings of the New Zealand Grassland Association 43:58-63.

Judd, T.G.; Thomson, N.A.; McCallum, D.A. 1990. Pasture management and pasture species for improved dry matter production in South Taranaki. Proceedings of the New Zealand Grassland Association 51:109-112.

L'Huillier, P.J.; Thomson, N.A. 1988. Estimation of herbagemass in ryegrass/white clover dairy pasture. Proceedings of the New Zealand Grassland Association 49:177-122.

O'Connor, M.B.; Cumberland, G.L.B. 1973. Nitrogen responses on pasture. Proceedings of the Ruakura Farmers Conference 25:137-144.

Paul, K.J. 1985. A new direction for the payment of milk. Proceedings of the Ruakura Farmers Conference 37:77-85.

Roberts, A.H.C.; Thomson, N.A. 1984. Seasonal distribution of pasture production in New Zealand XVIII. South Taranaki. New Zealand journal of experimental agriculture 12:83-92.

Roberts, A.H.C.; Thomson, N.A. 1989. Use of nitrogen fertiliser for intensive dairy production. In Nitrogen 
in New Zealand Agriculture and Horticulture, Ed. R.E. White, L.D Currie. Fertiliser and Lime Research Centre, Massey University. Occasional Report No. 3:42-53.

Thomson, N.A. 1985. Pasture allowance: "The main course principle". Proceedings of the Large Herds Conference 16: 18-20.

Thomson, N.A.; Lagan, J.F. 1981. Lucerne not the answer to dairying. New Zealand Journal of Agriculture (May 1991):13-17.

Thomson, N.A.; Lagan, J.F.; McCallum, D.A.; Prestidge, R. 1988. A n evaluation of Grasslands Roa tall fescue and Grasslands Maru phalaris for dairying. Proceedings of the New Zealand Grassland Association 48:187-191.

Thomson, N.A.; Roberts, A.H.C. 1982. Response to nitrogen fertiliser applied to dairy pastures in autumn and spring in Taranaki. Proceedings of the New Zealand Grassland Association 43:44-52. 